\title{
Relationship Between Social Responsibility and Financial Performance of Listed Companies in Tehran Stock Exchange
}

\author{
Vahideh Akbari, Abdorreza Asadi \\ Islamic Azad University, Neyshabur Branch, Iran
}

\begin{abstract}
The aim of this study was to investigate the relationship between social responsibility and financial performance of the companies accepted in the Tehran stock exchange. Corporate social responsibility, through the questionnaire containing 20 questions in the field of social responsibility towards clients, employees, the environment, and the existing institutions in the Community is measured. These data are related to the company's 65 during the years 2008 up to 2013 for the analysis of data from the regression method that is used. The research results showthatfinancial performance with social responsibility towards the environment is a meaningful relationship. But the company's financial performance with social responsibility towards employees, customers, and the existing institutions in the community does not have a significant relationship. This study will help manager's effective policies relating to corporate social responsibility, which is to achieve a better financial performance, in the long run, they need to develop, as well as insights for companies in the field of the role of social responsibility in the future interests of the business.
\end{abstract}

Keywords:social responsibility, financial performance, Tehran stock exchange

\section{Introduction}

The purpose of corporate social responsibility, the integration of activities, and the values of the organization in such a way that the interests of all shareholders, including suitable competent customers, employees, investors, and the general public, reflected in the organization's policies and performance can be applied (Foroughi, 2008; Mousavi, Akbari,\& Rezaei, 2011). Nowadays, many pundits believe that for some reason, such as privatization and transfer of economic power from the state to the organization and therefore smaller size of Government to solve social problems do not have the necessary resources and power to resolve this problem, as a result, governments should help in this field (Dkhili \& Ansi, 2012; Kohansal \& Akbari, 2013).

In recent years, the theory expressed that units can create wealth, employment, and innovationto supply the market and to strengthen their activities and to improve their competition if they have to maintain their self-social setup that has an essential role, and also in front of the community by providing the necessary conditions in order to earn trust by investors and create efficiencies for the beneficiaries of the absence of arbitrage activities and unjust substrates suitable for the development and advancement of commercial units and providing (Sandhu \& Kapoor,2010).

Vahideh Akbari, M.Sc. student of Management, Department of Management, Islamic Azad University, Neyshabur Branch, Iran. Abdorreza Asadi, assistant professorof Finance, Department of Management, Islamic Azad University, Neyshabur Branch, Iran.

Correspondence concerning this article should be addressed to Abdorreza Asadi, Department of Management, Islamic Azad University, Neyshabur Branch, Iran. Email: abdorrezaasadi@yahoo.com. 
Hovard Boon (1953), with his impressive book titled Social Responsibility Businessman, Academic Management, and Organization in the literature, expresses the concept of social responsibility for the first time.

In the book, Bowen noted that the social responsibility of a trader is a commitment to the pursuit of policies and decisions and actions that are in line with the objectives and social values. The journey of transformation and social accountability management approach in three historical stages can be studied.

(1) since 1930 till 1800

The dominant view in the course of this has been in economic and commercial enterprises and institutions, responsible for providing benefits and earning maximum profits for themselves.

(2) since 1930 to 1960

The result of the exploitation of the workers and ignoring their human rights, is the course of a very important move. Dispersed workforce is operating in the CapitaLand against the owners of industries than before the injury, no one else on the organization and the trade unions. These unions as legal workers, representatives with leverage strike on companies strike lever on the side of their own interests, the interests of workers.

(3) from 1960 to present

In this period, more societies realized environmental impacts, economic enterprises, and industries are giant, and as a result, it comes to the attitude that because society allows trading activity and the growth of the institutions and the aforementioned organizations are the same scarce resources of people and a good environment to study community created the profits they should be serving the public, so that the institutions and the community have the right for the sake of the well-being of the public, they will control.

\section{Social Responsibility and Financial Performance}

Desire and urge business units to the commitment are social responsibility in all dimensions of a significant effect on the financial performance.In fact the tendency towards social responsibility is to encourage trade, to improve the environment, to use less energy and materials, to manage the activity, etc. (Sandhu \& Kapoor,2010; Mehrjerdi, Talebi, \& Akbari, 2014).

As a result, the commercial units can be long-term returns through the reduction of the negative effects of its community, an optional maximum tort. Meanwhile, today, this school of thought among the business units for increasing is the formation of long-term success that they can manage the company's operations with environmental protection and ensure the advancement of corporate social responsibility to come true. So the implementation of corporate social responsibility contributes to improving the success of companies in the long term, and eventually leads to economic growth and increasing the competitive power of the company and its financial performance is improved.

Based on the research that has taken place, there are three types of positive, negative, and neutral (no relation) between social responsibility and financial performance of the company.

The first view is that the relationship between the cost of a little company, such as the payment of interest to the holders of the bonds, the cost of production, or the quality of them, such as quality, security costs there. The efforts of companies to bear the cost of a less quality through social activities to the cost are a little higher. Also effect of consensus theory is the basis for a positive relationship between the social performance and financial performance of the company. In fact, this theory proposes that non-beneficiaries of the company's total supply the needs of the owner's positive impact on financial performance. 
The second view is that successful companies financially fewer resources in creating their high financial performance which is the result of the work can be the greater part of their resources to social performance.

The third view was also expressed that the companies that accept more social responsibility are less exposed to the risk of negative events because they are less likelymany heavy fines for pollution (environment) payment, or there is little likelihood that costly lawsuits against them exist, or rarely a negative social activity that may be damaging to their credit, that these cases are finally on the financial performance of the company positive acknowledgement. The negative relationship between social responsibility and financial performance of the company is with my thoughts and neoclassical economists and freedman compatible. They are stating that social responsibility can make companies incur expenses that eventually lead to lower profits and shareholders' wealth. The hypothesis of opportunism of management is the result of a negative relationship between the basis for the company's social responsibility and financial performance.

Arab Salehi (2013) explores the relationship between social accountability as the financial performance of the companies accepted on the Tehran stock exchange through a questionnaire that contains 53 questionsaccountable to the following four employees, customers, the environment, and measured the existing institutions in the community and finally concluded that the financial performance of companies with corporate social responsibility relates to the customers and the existing entity in the Community association. But the company's financial performance with social responsibility towards employees and the environment does not have a significant relationship.

Banimahd, Talebnia, and Arooji (2009)examine the relationship between environmental performance and financial performance of the companies accepted on the Tehran stock exchange in 2001-2008. The aim of the study was to investigate the relationship between environmental performance and financial performance and a model of environmental performance indicators. In this study, the ISO certification 14000 and the financial performance indicators include indicators of Tobin, the ratio of operating profit, and cash flow asset to collectors. The result of the research indicates the environmental performance index, a significant correlation with financial performance.

Jbarzadeh and Bayazidi (2010) study the relationship between social accountability and organizational commitment with conservatism in the financial reports of the company Gary TSE accepted. In this study, the number of accepted company 115 in Tehran stock exchange during the period 2002-2008 is used. The research findings show the relationship between the ethical structures (corporate social accountability and organizational commitment) and conservatism has been positive but only a variable relationship between corporate social responsibility and conservatism in terms of meaningful statistics.

Fauzi (2008) studies the impact of the relationship between corporate social performance and financial performance. The purpose of this article is about the relationship between CSR and CFP using the potential of the field of vision caused by strategic management. This review uses the theory of scarce resources and management theories. This study is expected to provide a new insight into the relationship between corporate social performance using outlook as a strategic proposal for possible accounting and management literature raised in previous research that has not been discussed.

\section{Research Hypothesis}

With regard to the questions raised, the following hypothesis for the present research:

(1) Social accountability in respect of the financial performance of the company's employees has a 
meaningful relationship.

(2) Social responsibility in relation to the customers with the company's financial performance has a significant relationship.

(3) Social accountability in relation to the environment with the financial performance of the company has a significant relationship.

(4) Social accountability in the relationship with existing institutions in the community with performance the company's financial relationship is significant.

\section{Research Methodology}

This research in terms of the objective applied research methods used in this research is descriptive research method-solidarity because of the expression of the relationship between social responsibility and financial performance of the company. It is for descriptive variable that cannot be tampered with and that the status quo is to identify them.

In order to test the hypothesis of research, the regression method is used and the default test usesthe regression model to include the normal tests and test the camera Watson errors that cannot be relied on to ensure the results being applied (Ghayoumi \& Momeni, 2010). The preparation of the compiled information is used from Excel software and to test the hypothesis used Eviews software. In the literature section of the library and study in order to gather information in the field of corporate, social responsibility index of standardized questionnaire has been used. This questionnaire is composed of four parts; each part can be measured with a variety of Likert.

\section{The Statistical Community and the Method of Sampling}

In this study, the method is used for the knockout. Statistical research community includes the companies accepted on the Tehran stock exchange that has the following characteristics:

- Before the start of the fiscal year 1387 are stock.

- Company's fiscal year ended on 29 March of each year.

- Manufacturing activity and therefore financial institutions, insurers, investment companies bank due to the different nature were not included in the sample.

- Participating in the fiscal year has not changed during the period of investigation.

- The company's shares whichhave been traded are listed.

- 14000ISO or at least reported social performance is the quality management standard.

- Information management requirements (the explanatory notes to the financial statements) are available.

The above-mentioned companies in 2008-2013 arefor the samples, when a section is selected. Limiting the period of this research to a five-year interval since it is while taking advantage of an acceptable interval for hypothesis testing, of prolonging the period of research viewed as the lack of consistency of economic conditions on the course to follow is to abstain.

\section{Research Variables}

\section{Independent Variable}

Social accountability as independent variable inthe study with four employees, customers, the environment, and the existing institutions in a society can be measured. This variable by using a list that is Likertwith a variety of 20questions can be measured. It is noteworthy that list questions data extraction by the researcher 
after reading the report of the Board of Directors of the stock exchange on the site, like every year, will release (SEO) answered. These dimensions are as follows:

(1) social accountability in connection with the staff: includes aspects such as the health of the environment, employees, staff training, staff benefits, employee share ownership, and the safety and health of employees (ISO 18000), questions from 1 to 6 in the questionnaire are related to this section, and in order to test the first hypothesis is being used.

(2) social accountability in relation to customers: includes aspects such as use of the product recipes and volunteering in the case of health and safety services and products as well as product quality (ISO 9000) and questions from 7 to 10 in the questionnaire are related to this section, and in order to test the second hypothesis is being used.

(3) social accountability in relation to the environment: includes aspects such as the percentage of the use of recycled materials and reducing the company's malware works on the environment, air pollution, and the prize in the field of the environment, questions from 11 to 14 in the questionnaire are related to this section, and in order to test the third hypothesis is being used.

(4) social accountability in the relationship with existing institutions in the society: includes aspects such as policies that reflect the influence of company activities in the community and encourage related awards and incoming social, cultural activities such as cash donation program, a charitable program, scholarship program, sponsors for sports activities, questions from 15 to 20 in the questionnaire are related to this section, and in order to test the hypothesis used IV.

Method of measurement of the variable of social accountability:

For the measurement of social accountability standard questionnaire variables have been set up with a variety of Likert. According to the announcement from the company snapshots that are on the site or other sites (SEO) of the stock exchange are available to each question whichcan be answered and ended up with a ranking to each response with the use of this software, the measurement variable. Continue on with more examples and explanations to understand the subject better.

- Measurement of social responsibility in relation to the following employees: to evaluate this dimension we need six criteria:

(1) Health of the environment staff

(2) Staff training

(3) Staff benefits

(4) Staff profile

(5) Employee shares ownership

(6) Safety and health of employees

Question for any plan and finally with regard to the report of the Board of Directors declared the company to these questions can be answered which can be due to a variety of Likert one of the options: very good, good, average, bad, very bad.They were considered after responding to all questions relevant to the rating next to the stages that every answer your specific points will be found. Very good: 4, good: 3, average: 2, bad: 1, and finally to zero and no very bad option a score does not belong.

After gathering them on the number of points each after the split that the criteria for the next six employees were taken into consideration of criteria to this case: 
$\mathrm{EM}=\Sigma \mathrm{A} / 6(1)$

- EM: social accountability in the relationship with employee's social accountability.

- A: score for each of the company's staff relations criteria j.

- The number 6 in the denominator indicates the six criteria for this later.

- Measurement of social responsibility in relation to customers:

To show it after the accountability we considered four criteria:

(a) product safety

(b) product quality (ISO 9000)

(c) product development

(d)after sales service

Social accountability score for later customers as follows:

$\mathrm{CO}=\Sigma \mathrm{C} / 4(2)$

- CO: social accountability in the relationship with customers.

- C: accountability for each of the criteria customers in company $j$.

- The number 4 represents the number of criteria for this later.

- Measurement of social responsibility in relation to the environment:

To assess this, we need the following four criteria:

(a)control of air pollution

(b) the program of prevention and compensation

(c)the protection and use of the products resulting from recycling

(d)prize in the field of environment (ISO 14000)

Social accountability score after the following response to the questions comes from the formula:

$\mathrm{EN}=\Sigma \mathrm{D} / 4(3)$

- EN: social accountability in relation to the environment.

- D: score accountability for each of the environmental criteria in company $\mathrm{j}$.

- The number 4 represents the number of criteria for the next.

- Measurement of social responsibility in relation to the existing institutions in the community:

For the amount of social responsibility with the existing institutions in the community related to need to six criteria:
(a) cash donation program
(b) charity program
(c) scholarship program
(d) the sponsors for sports activities
(e) national pride sponsors
(f) public projects

$\mathrm{SO}=\Sigma \mathrm{F} / 6(4)$

- SO: social accountability in relation to the existing institutions in the community.

- F: social accountability score for each of the criteria of the Community institutions, in the company of $j$.

- The number 6 in the denominator indicates the six criteria for this later. 


\section{Dependent Variable}

The financial performance of companies is measured with three variables: liquidity index, value added of the market, and the ratio of the Q Tobin.

liquidity: this variable is the most important decision index in the stock as follows:

liquidity $=$ published the total shares of the company at the end of the year/ number of shares traded in the company during the year(5)

2. value added of the market: the wealth of the shareholders through maximizing the difference between the market value of shares of the company and the amount funded by the shareholders to the pinnacle of this difference, the market value added (MVA) is called.

value added of the market $=$ price per share number of shares by the end of the year-

income of ownerstake $\operatorname{stock}(6)$

3. the ratio of the share of the company's market value: Q Tobinto get the value of the company's asset Office comes out:

$$
\mathrm{Q} \text { Tobin }=\text { Total assets/(total debt }+ \text { market value of total shares })(7)
$$

\section{Control Variables}

In the present study, the company's size and structure of the variables property as the control variable is considered.

1. The size of the company: measured by a number of assets

$$
\text { SIZE }=\text { LN (ASSETS)(8) }
$$

Ownership structure: The ownership structure into three groups for categories of public, private, and institutional companies are classified.

\section{Hypothesis Testing Models}

The significance or insignificance model, the following assumptions can be expressed in the form; in other words original research hypotheses $\mathrm{H} 1$ and $\mathrm{H} 0$ are as follows:

H1: Social responsibility performance

H0: Social responsibility on financial performance

\section{Linear Regression Model}

$$
\text { CFPindex }=B_{\circ}+\sum_{n=1}^{4} B_{n} \text { CSR index }_{i t}+\sum_{i=1}^{2} \gamma_{i} \text { contorol }+\varepsilon_{i t}(9)
$$

- B: Fixed

- CFP: Financial Performance

- CSR: Responsibility

Continue to check the formula for the overall regression formula that is more minor above with respect to the independent variable dependent dimensions, and we control and end up using the same formula that the relationship between the dependent and independent variables can be measured.

$$
\begin{gathered}
Q=B 0+B_{1} E M+B_{2} C O+B_{3} E N+B_{4} S O+B_{5} \text { size }+B_{6} \text { Inst }+B_{7} \text { Pow }+B_{8} \text { Fow }+\varepsilon_{i t} \\
L I=B 0+B_{1} E M+B_{2} C O+B_{3} E N+B_{4} S O+B_{5} \text { size }+B_{6} \text { Inst }+B_{7} \text { Pow }+B_{8} F o w+\varepsilon_{i t} \\
M V A=B 0+B_{1} E M+B_{2} C O+B_{3} E N+B_{4} S O+B_{5} \text { size }+B_{6} \text { Inst }+B_{7} \text { Pow }+B_{8} \text { Fow }+\varepsilon_{i t}
\end{gathered}
$$


- LI: Liquify

- MVA: Market value added

- Q: Tobin's Q

- EM: Employment

- EN: Environment

- SO: Society

- CO : Customer

- Inst: Institutional ownership

- Pow: Public property

- Fow: Private property

\section{Results}

\section{The First Models Were Fitted}

The first model of the research must be at least squares regression with random effects, waterfalls decorative fitted.

Table 1

The First Models Were Fitted Result

Dependent variable $=\mathrm{Q}$ Tobin

\begin{tabular}{|c|c|c|c|}
\hline \multicolumn{4}{|c|}{ Dependent variable $=\mathrm{Q}$ Tobin } \\
\hline \multicolumn{4}{|c|}{ The method of least squares regression fit model: random effects with waterfalls decorative } \\
\hline Variable & Coefficient & Standard deviation & $\mathrm{T}$ \\
\hline $\mathrm{C}$ & $24 / 714$ & $2 / 755$ & $8 / 972$ \\
\hline Responsibility towards the environment & $0 / 767$ & $0 / 204$ & $3 / 750$ \\
\hline Responsibility towards customers & $0 / 047$ & $0 / 226$ & $0 / 206$ \\
\hline Responsibility towards employees & $-0 / 077$ & $0 / 172$ & $-0 / 450$ \\
\hline Accountability towards the institutions & $-0 / 063$ & $0 / 227$ & $-0 / 275$ \\
\hline Institutional ownership & $-0 / 012$ & $0 / 271$ & $-0 / 045$ \\
\hline Public property & $-1 / 443$ & $0 / 482$ & $-2 / 996$ \\
\hline Private property & $0 / 144$ & $0 / 591$ & $0 / 243$ \\
\hline The size of the company & $-0 / 487$ & $0 / 201$ & $-2 / 419$ \\
\hline$\left(R^{2}\right)$ & 0.97 & & \\
\hline Durbin-Watson & 1.46 & & \\
\hline $\mathrm{F}$ & 112.330 & & \\
\hline
\end{tabular}

The value of the F-statistic is significant and 330.112 against corresponding with this statistic against the 0.0 that has a lesser amount of malpractice is 5.0 , so the hypothesis $\mathrm{H} 0$ which was expressed at the top will be rejected. In other words, 95 percent sure we can be claimed.

Fitted regression least squares regression method, the random effects models with waterfalls decorative first significant study. "as well as a number of statistics is 46.1 Watson against the camera. If this is a value between 1 and 5.2 statistics, their lack of correlation of sentences we can see that the error is also a responsibility towards the environment"with the company's performance as an indicator of Tobin significant relationship. And "the responsibility towards the customers with the company's performance as an indicator of Tobin index relationship is not significant". And "the responsibility towards the employees with the company's performance as an indicator of Tobin index the relationship is not significant. And accountability towards the 
institutions with Tobin as the company's performance index does not have a significant relationship".

\section{The Second Model Fitted to Study}

The second model of the research must be at least squares regression with random effects, waterfalls decorative fitted.

Table 2

The Second Models Were Fitted Result

Dependent variable $=$ liquidity index

\begin{tabular}{llll}
\hline \multicolumn{4}{c}{ The method of least squares regression fit model: random effects with waterfalls decorative } \\
\hline Variable & Coefficient & Standard deviation & $\mathrm{T}$ \\
\hline $\mathrm{C}$ & $-11 / 296$ & $1 / 744$ & $-6 / 478$ \\
Responsibility towards the environment & $0 / 436$ & $0 / 194$ & $2 / 249$ \\
Responsibility towards customers & $0 / 600$ & $0 / 200$ & $3 / 000$ \\
Responsibility towards employees & $0 / 003$ & $0 / 208$ & $0 / 015$ \\
Accountability towards the institutions & $-0 / 290$ & $0 / 282$ & $-1 / 029$ \\
Institutional ownership & $-0 / 463$ & $0 / 379$ & $-1 / 220$ \\
Public property & $-1 / 301$ & $0 / 467$ & $-2 / 785$ \\
Private property & $-0 / 302$ & $0 / 577$ & $-0 / 522$ \\
The size of the company & $0 / 252$ & $0 / 125$ & $2 / 024$ \\
$\left(R^{2}\right)$ & 0.86 & & \\
Durbin-Watson & 1.89 & & \\
F & 26.326 & & \\
\hline
\end{tabular}

The value of the statistics that evaluating $\mathrm{F}$ fitting model deals with significant results, is significant and 326.26 against corresponding with this statistic against the 0.0 that has a lesser amount of malpractice is 5.0, so the hypothesis H0 which was expressed at the top will be rejected. In other words, $95 \%$ can be claimed with certainty:

Fitted regression least squares regression method, the random effects with waterfalls decorative. The second model is based on significant research.

As well as the number of statistics is 89.1 Watson against the camera. If this is a value between 1 and 5.2 statistics, their lack of solidarity causes error. See also:

"The responsibility towards the environment with liquidity index as an indicator of the performance of the company's significant relationship." And "the responsibility towards the customers with liquidity index as an indicator of the performance of the company's significant relationship." And "the responsibility towards the employees with the company's liquidity index as an indicator of performance."

The relationship is not significant. And accountability towards the institutions with liquidity index as an indicator of the performance of the company is not a significant relationship.

\section{The Third Study, Fit Modeling}

The third model of the research must be as least squares regression with random effects, waterfalls decorative fitted.

In the above table for the view, the value of the statistics that evaluating $\mathrm{F}$ fitting model deals with significant results, is significant and 251.6 against corresponding with this statistic against the 0.0 that has a lesser amount of malpractice is 5.0, so the hypothesis H0 which was expressed at the top will be rejected. In 
other words, 95 percent sure can be claimed.

Table 3

The Third Models Were Fitted Result

\begin{tabular}{|c|c|c|c|}
\hline \multicolumn{4}{|c|}{ Dependentvariable $=$ valueaddedofmarket } \\
\hline \multicolumn{4}{|c|}{ Themethodofleastsquaresregressionfitmodel:randomeffectswithwaterfallsdecorative } \\
\hline Variable & Coefficient & Standard deviation & $\mathrm{T}$ \\
\hline $\mathrm{C}$ & $19 / 303$ & $1 / 137$ & $16 / 970$ \\
\hline Responsibilitytowardstheenvironment & $0 / 489$ & $0 / 129$ & $3 / 786$ \\
\hline Responsibilitytowardscustomers & $0 / 070$ & $0 / 313$ & $0 / 223$ \\
\hline Responsibilitytowardsemployees & $0 / 079$ & $0 / 109$ & $0 / 730$ \\
\hline Accountabilitytowardstheinstitutions & $0 / 014$ & $0 / 124$ & $0 / 110$ \\
\hline Institutionalownership & $0 / 056$ & $0 / 207$ & $0 / 270$ \\
\hline Publicproperty & $-0 / 756$ & $0 / 348$ & $-2 / 168$ \\
\hline Privateproperty & $0 / 163$ & $0 / 382$ & $0 / 428$ \\
\hline Thesizeofthecompany & $0 / 530$ & $0 / 086$ & $6 / 162$ \\
\hline$\left(R^{2}\right)$ & 0.94 & & \\
\hline Durbin-Watson & 1.46 & & \\
\hline $\mathrm{F}$ & 65.251 & & \\
\hline
\end{tabular}

Fitted regression method based on random effects model with the lowest third waterfalls decorative study was significant.

As well as the number of statistics is 46.1 Watson against the camera. If this is a value between 1 and 5.2 statistics, their lack of solidarity causes error. See also:

"The responsibility towards the environment with the added value of the market as an indicator of the performance of the company's significant relationship." And "the responsibility towards the clients with the added value of the market as an indicator of the performance of the company is not a significant relationship." And "the responsibility towards the staff with the added value of the market as an indicator of the performance of the company is not a significant relationship." And "accountability relative to existing institutions, with the added value of the market as an indicator of the performance of the company, the relationship is not significant."

\section{Summary of the Results}

The results obtained in this chapter can be briefly stated as follows:

Table 4

Hypothesis Test

\begin{tabular}{|c|c|c|}
\hline Hypothesis & Hypothesis title & Result \\
\hline & $\begin{array}{l}\text { Social accountability in respect of the financial performance of the company's employees with a } \\
\text { meaningful relationship. }\end{array}$ & reject \\
\hline & $\begin{array}{l}\text { Social accountability in respect of the financial performance of the company's customers with } \\
\text { meaningful communication. }\end{array}$ & reject \\
\hline & $\begin{array}{l}\text { Social accountability in relation to the environment with the financial performance of the } \\
\text { company has a significant relationship. }\end{array}$ & accept \\
\hline & $\begin{array}{l}\text { Social accountability in the relationship with existing institutions in the community with the } \\
\text { financial performance of the company has a significant relationship. }\end{array}$ & reject \\
\hline
\end{tabular}

The result of the research showed the social accountability in relation to employees with no significant 
relationship between financial performance and the first hypothesis was rejected. As shown in the research of social accountability in relation to financial customers with functioning of the relationship is not significant but has seen that in the review of the financial performance of the Liquidity index a significant relationship, but with two other indicators that the cave is the market varnish. Tobin added no significant relationship observed social accountability in relation to the environment is a significant relationship between the financial performance and the third hypothesis was accepted. The estimated model showed that between social accountability in the relationship with existing institutions in the community with financial performance there is no significant relationship.

\section{Discussion and Conclusions}

Results of the analysis showed the social accountability in relation to the environment in the environment only with the financial performance of a significant relationship. This topic indicates that observing corporate accountability in the field of the environment is the positive effect of corporate technology based and can cause an increase in corporate investment. The main reason for the emphasis on the relationship between social accountability on financial performance is that the existence of a connection between these two corporate compliance issues is caused by that time in favor of the owners of the shares eventually and the community. Research shows that there is a positive relationship between these two variables to maintain the interests of the shareholders, stakeholders, and transition effects. In other words, do not observe the social accountability to non-ethical behaviors and mistrust in order to reduce the value of the lead company (Marhani, 2009).

\section{The Limitations of the Research}

This research also has limitations and obstacles that continue to point them out.

(1) The main restrictions on this research was limited access to the community.On the one hand, all the affiliate member companies provide information exchange between 1387 and 1392 . However, the researcher all available community through systematic removal that was obtained for example is considered.

(2) It lacks a comprehensive benchmark for assessing corporate social responsibility.

The following proposal for the use of the results of the research will be presented:

According to the third theory, that being accepted to examine the relationship between social accountability in relation to the environment with the financial performance of the company is always trying and taking issues such as prevention of pollution in air, water pollution, the discharge of waste production at least, the lack of a comprehensive and liquid waste production, use or disposal of toxic and hazardous chemicals and other pollutants. Resulting from their activities, your organization's financial performance can be improved further in the long run and significant profitability can be seen.

\section{Suggestions for Future Research}

(1) Using the variable of adjustment if the direction of the relationship between social responsibility and financial performance.

(2) Study the relationship between financial performance and other dimensions of social accountability in other countries, as well as those mentioned in the international standard ISO 26000.

(3) The relationship between social accountabilityand other financial performance criteria.

\section{References}


A group of Experts on Iran. (2007). Corporate social responsibility CSR approach EFQM model and management quality publications in cooperation with the publishing Marand Yazd.

Ahmad Pur, E. (2010). The effect of corporate governance and audit quality on the cost of financing through debt. Review of Accounting and Auditing, 14(62),17-33, Winter 1389.

Almasi, M. R. (2002). Brrsy impact of privatization on the financial performance of companies listed on the stock exchangeTehran stock. The master's thesis. Faculty of Economics, Management and Social Sciences, Shiraz University.

Ansari, M. (2012). Social responsibility accounting, project finance, accounting and management disciplines, projects.

Arab Salehi, M. (1392). The relationship between social responsibility and financial performance of companies listed on the Tehran stock exchange.Empirical Research in Accounting, 4, 1-20.

Banimahd, B., Talebnia, B.C., \&Arooji, H. (2009). The relationship between environmental performance and financial performance.Journal of the National Accounting and Auditing,149-174.

Bassen, A., Hölz, H. M., \& Schlange, J. (2006). The influence of corporate response ability on the cost of capital: An empirical analysis.http://ssrn.com/abstract

Brien, D. (2007). Integrate corporate social responsibility which competitive strategy. The Center for Corporate Citizenship at Boston College.

Chili, H.,\& Ansi, H. (2012). The link between corporate social responsibility and financial performance: The case of the Tunisian companies. Journal of Organizational Knowledge Management.

Dam Lampert, A. (2006). Corporate social responsibility and financial performance. M.A. dissertation,University of Groningen, 25-29.

Duaei, H., Fathi, A., \&Shykhyanf, A. K. (2006). Taking the green path to a sustainable competitive marketing. Gimmick No. 173, 21-33.

Ehsan, S., Kaleem, A., \& Jabeen, S. (2012). Exploring the interaction between financial performance and corporate social responsibility in Pakistani firms. Journal of Basic and Applied Scientific Research, 2(10), 10431-10439.

Erhemjamts, O., Li, Q., \&Venkateswara, A. (2012). Corporate social responsibility and the impact on firm investment policy. Organizational Structure and Performance Discussion Paper Series,1-45.

Fauzi, H. (2008). The determinants of the relation ship of corporate social performance and financial performance: Conceptual framework.Discussion Paper Series in Turn, 1-32.

Foroughi, D. (2008). Social attitudes of managers on accounting information disclosure of listed companies in Tehran stock exchange.Accounting and Audit Review, 15,55-70, Summer 2008.

Ghasemi, A. (1995). Evaluation of social responsibility managers for textile industry national industry organization. Master thesis, School of Management.

Guillaume, P. (2013). Corporate social responsibility and financing decisions.Managerial Auditing Journal, 1-38.

Hajipour, B. (2011). Strategic alliance AA. The effect on the relationship between organizational learning, innovation and financial performance.Journal of Management Studies Improvement and Progress, 1(64), 141-166.

Jabarzadeh, Q., \& Bayazidi, B. (2010). Examined the relationship between social responsibility and commitment to conservative financial reporting of companies listed on the stock exchange, 9, 77-96.

Jensen, M. C. (2001). Value maximization, stakeholder theory and the corporateobjective function. Journal of Applied Corporate Finance, 14(3), 8-21.

Jiao, Y. (2010). Stakeholder welfare and firm value. Journal of Banking and Finance, 34, 2549-2561.

Jun. M. A. (2012). A study on the models for corporate social responsibility of small and medium enterprises.Hong-Kong Journal of International Financial Management, 128-160.

Kohansal, M. R., \& Akbari, M. R. (2013). Grain Marketing Margins Evaluation in Iran a Case Study: Bean. International Journal of Agriculture and Crop Sciences, London, 6 (15), 1088-1091.

Kohansal, M. R., Dogani, A., \& Akbari, M. R. (2013). Management of water agriculture regarding to profit index (Case study: Mashhad-Chenaran weald in Iran). International Journal of Agriculture and Crop Sciences, London, 6 (11), 617-622.

Mahoony, L.,\& Roberts, R. (2007). Corporate social and environment performance and their relation to financial performance and institutional ownership.Accounting Forum 2007, 31(3), 233-253.

Margolis, J. D.,\& James, P.W. (2001). Misery loves company whether social initiatives by business. Harvard Business School Working Paper Series, 1-58.

Mehdi Zadeh, N. (2008). The relationship between social responsibility and according to the company's marketing performance. Central School master's thesis, non-profit institution of higher education Ghadir.

Mousvi, S. N., Akbari, M., \&Rezaie, M. (2011). Estimating the preservation and outdoor recreation values of Iran forests and 
forest parks. American-Eurasian Journal of Agricultural \& Environmental Sciences, 11(4), 551-558.

Mousavi, S. N. A., Mohammadi, H., \& Akbari, S. M. R. (2011). Impacts of Governments Fiscal Policies on Value Added of Agriculture And Industrial Sectors. Journal of Agricultural Economics Research, 2 (4), 121-134.

Mousavi S. N., Rosta, A., Keshavarz, S., \& Akbari, S. M. R. (2011). Effective Factors on agricultural productions Variation in Iran Using Entropy Index. Journal of American science, 7 (6), 1039-1043.

Mousavi, S. N. A., Sedghi, N., \& Akbari, S. M. R. (2011). Comparative advantage of grape production in Fars province. Life Science Journal-ACTA Zhengzhou University Overseas Edition, 8 (3), 113-116.

Mousavi, S. N., \& Akbari, S. M. R. (2011). Estimated value of forest conservation in Iran: A case study of Fars Province. African Journal of Agricultural Research, 6 (30), 6407-6411.

Niyazi, A. R., \& Amini, G. (2008). Standards of social responsibility.Quality Control Magazine.

Omidvar, A. R. (2008). Journal of Corporate Social Responsibility.Center for Strategic Research.

Pourali, M. R. (2014). The brrsy relationship between social responsibility disclosure and institutional ownership in companies listed on the Tehran stock exchange. Journal of Management Accounting Knowledge.

Royaei, R. (2009). The role of cultural managers in promoting social responsibility.A Social Science Research,8.

Sandhu, H. S.,\& Kapoor, S. (2010). Corporate social responsibility initiatives: An analysis of voluntary corporate disclosure. South Asian Journal of Management, 17(2), 47-80.

Senobar, N. (2010). The relationship between corporate social responsibility and financial performance.Journal of Business Administration Excavations, 4,51-58.

Servaes, H., \&Tamayo, A. (2012). The impact of corporate social responsibility on firm value: The role of customer awareness. http://ssrn.com/abstract=2116265

Setiawan, M., \& Darmawan, L. (2011). The relationship between corporate social responsibility andfirm financial performance: Evidence from the firms listed in LQ45 of the Indonesian stockexchange market. European Journal of Social Sciences, 23(2).

Soltani, I. (2006). The role of social responsibility in achieving competitive advantage. Gimmick No. 169, 28-32.

Turabi, C., Heidari, A., \& Quli Tarzan, C. (2010). Effect of co-operative component of social responsibility in corporate financial performance. Case Study of Livestock and Poultry Cooperatives in the City of Mashhad, the Twenty-First Year of Operation, the New Course,2,1-20.

Mehrjerdi, M. Z., Talebi, K., \& Akbari, S. M. R. (2014). The role Of knowledge processing management in sme development and economic growth. In Economic and Social Development, 7th International Scientific Conference, Book of Proceedings (677). Design Print Varazdin Development and Entrepreneurship Agency, Varazdin, Croatia.

Mehrjerdi, M. Z., Talebi, K., \& Akbari, S. M. R. (2014). The role of knowledge processing management in sme development and economic growth. Economic and Social Development: Book of Proceedings, 677.

Talebi, K., Mehrjerdi, M. Z., \& Akbari, S. M. R. (2016). The role of knowledge processing management in sme development and economic growth. China-USA Business Review, 15 (3), 130-136.

Zarra Nejad, M., \&Anvari, E. (2005). Using panel data regression analysis methods in different sciences with an emphasis on economic sciences-social. Proceedings of the First International Conference on Research Methods, 211-215. 